\title{
Effect of the seed maturation stage and pre-germination treatments on emergence of Erythrina crista-galli L.
}

\author{
Thales Castilhos de Freitas 1,* (D), Gustavo Crizel Gomes ${ }^{2}$ (1), Ernestino de Souza Gomes Guarino ${ }^{3}$ (D), \\ Artur Ramos Molina ${ }^{4}$ (D), Fabricio Sanches Medeiros ${ }^{5}$ (1) , Luiz Carlos da Silva Souza ${ }^{6}$ (D), \\ Adalberto Koiti Miura ${ }^{3}$ (D), Letícia Penno de Sousa ${ }^{3}$ (D), Joel Henrique Cardoso?
}

\author{
Universidade Federal de Pelotas, Programa de Pós-Graduação em Ciências Ambientais (PPGCamb - UFPel), \\ Rua Benjamin Constant, 989, Porto, CEP: 96010-020, Pelotas, RS, Brasil \\ *Autor para correspondência: thales.castilhos@gmail.com \\ 2Universidade Federal de Pelotas, Programa de Pós-Graduação em Desenvolvimento Territorial e Sistemas Agroindustriais \\ (PPGDTSA - UFPel), Rua Gomes Carneiro, $n^{\circ} 01$, sala 416, Campus Porto, $4^{\circ}$ andar, CEP: 96010-610, Pelotas, RS, Brasil \\ ${ }^{3}$ Embrapa Clima Temperado, Rodovia BR-392, Km 78, $9^{\circ}$ Distrito, Monte Bonito, CEP: 96010-971, Pelotas, RS, Brasil \\ ${ }^{4} \mathrm{CNPq}$ / Embrapa Clima Temperado, Rodovia BR-392, Km 78, $9^{\circ}$ Distrito, Monte Bonito, CEP: $96010-971$, Pelotas, RS, Brasil \\ ${ }^{5}$ Universidade Federal de Pelotas, Instituto de Biologia (IB - UFPel), Campus Universitário do Capão do Leão, s/ $\mathrm{n}^{\circ}$, \\ Travessa André Dreyfus, s/n Prédios 14, 17, 18, 20, 21, 22, 23, 24, 25 e 26, CEP 96010-900, Capão do Leão, RS, Brasil \\ ${ }^{6}$ Pesquisador independente, Av. Fernando Osório, 2301, Três Vendas, CEP: 96055-000, Pelotas, RS, Brasil \\ 'Embrapa Agroindustrial Tropical, Rua Dra. Sara Mesquita, n’2.270, Bairro Planalto do Pici, CEP 6051 1-1 10, Fortaleza, CE, Brasil
}

Recebido em 10.VIII.2019

Aceito em 04.III.2020

DOI 10.21826/2446-82312020v75e2020007

\begin{abstract}
The main goals of this study were to verify the existence of integumentary seed dormancy in Erythrina crista-galli seeds from mature pods and evaluate the seedling emergence from newly collected seeds in two stages of physiological maturation. Methods of overcoming dormancy were tested by comparing seedling emergence rate, mean emergence time and emergence index, with treatments: TC - control; T1- sanded and soaked in water for $48 \mathrm{~h} ; \mathrm{T} 2$ - sanded and soaked in water for $24 \mathrm{~h}$; T3 - soaked in water without heating at the initial temperature of $60{ }^{\circ} \mathrm{C}$, until reaching room temperature; T4 - only sanded; T5 - immature seeds. The results indicate that: i) newly collected seeds from mature pods do not require treatment to overcome dormancy; ii) immature seeds have germination similar to newly collected mature seeds.
\end{abstract}

Keywords: cockspur coral tree, Fabaceae, physical dormancy

RESUMO - Efeito do estágio de maturação e tratamentos pré-germinativos na emergência de Erythrina crista-galli L. Os objetivos deste trabalho foram verificar a existência de dormência tegumentar em sementes maduras de Erythrina crista-galli e avaliar a emergência de plântulas de sementes recém-coletadas, em dois estágios de maturação fisiológica. Foram testados métodos de superação de dormência, comparando-se taxa de emergência, tempo médio de emergência e índice médio de emergência das sementes, sendo os tratamentos: TC - controle; T1 - lixadas e embebidas em água por $48 \mathrm{~h}$; T2 - lixadas e embebidas em água por $24 \mathrm{~h}$; T3 - embebidas em água, fora do aquecimento, à temperatura inicial de $60{ }^{\circ} \mathrm{C}$ até atingir temperatura ambiente; T4 - apenas lixadas e T5 - sementes coletadas de legumes imaturos. Os resultados indicam: i) sementes recém-coletadas de vagens maduras não necessitam de tratamento para superação de dormência; ii) sementes imaturas apresentam germinação similar as maduras recém coletadas.

Palavras-chave: corticeira-do-banhado, dormência física, Fabaceae

\section{INTRODUCTION}

Erythrina crista-galli L. (Fabaceae, Papilionoideae), popularly known as cockspur coral tree, is a tree species which occurs from Maranhão State to Rio Grande do Sul State, being more recorded in the Brazilian South region (Martins 2019). Its distribution area also extends through Bolivia, Paraguay, Argentina and Uruguay (Mello et al. 2019). The species contributes to important environmental services, hosting several epiphytes species, and also attracting insects and hummingbirds due to their colorful flowering which give it an ornamental aspect (Gratieri-
Sossella et al. 2008). It is also of great value for medicine and ecological restoration (Mello et al. 2019). In Rio Grande do Sul State, the tree-cutting of this species is prohibited pursuant to Article 33 of State Law number 9.519/92 (Rio Grande do Sul 1992).

Due to the diverse assigned uses and environmental services that the plant offers, there is particular interest in its reproduction, which can occur through either asexually or sexually means (Gratieri-Sossella et al. 2008, Mello et al. 2016). Seed breeding is the most recommended when it is used for ecological restoration, seeking to collect as many local matrices as possible in order to sustain 
genetically stable populations (Sebbenn 2002). The species presents a phenological unevenness in the reproductive phase, occurring concomitantly during the fruiting, pods in different maturation stages (Gratieri-Sossella et al. 2008, Mello et al. 2013, Mello et al. 2016). Irregularity in the fruits maturation in a species in different populations or even in an individual is understood as a strategy to guarantee greater dispersion time and to reduce damage by predation (Willson \& Traveset 2000, Aquino et al. 2006).

The presence of integumentary dormancy is also commonly reported for the E. crista-galli (Silva et al. 2006, Mello et al. 2016). This type of dormancy is related to the impermeability of the integument or pericarp, which impedes the water absorption and gas exchange (Fowler $\&$ Bianchetti 2000), making the germination processes difficult, which in practice means lower germinability and/or germination speed. This is a common condition for seeds from species of the Fabaceae family (Silva $e t$ al. 2006). Unlike primary dormancy, which occurs during development in the mother plant, secondary dormancy is induced after dispersion when the seed is not submitted to favorable environmental conditions for germination, such as in the case of integumentary dormancy (Cardoso 2009). However, this type of dormancy can develop in the fast dehydration phase which occurs at the end of maturation, still in the mother plant (Baskin \& Baskin 1998). Some pre-germination treatments used for E. crista-galli are chemical scarification $\left(\mathrm{H}_{2} \mathrm{SO}_{4}\right)$, mechanical scarification and thermic scarification (hot water) (Silva et al. 2006; Mello et al. 2016).

The maturation stage in which the seeds are collected is also important for the germination process. Some characteristics can be used to define the most appropriate time for collection, known as maturation indexes, namely: color, size, moisture and dry mass of fruits and seeds (PiñaRodrigues \& Aguiar 1993). However, the most pratical aspects used for collecting seeds is the coloring of fruits and seeds (Aquino et al. 2006). In dehiscent fruits such as E. crista-galli, identifying the right moment for the collection is even more important because the seeds can be lost during the spontaneous opening of the fruits (PiñaRodrigues \& Aguiar 1993).

The main of this study was to verify the existence of seed coat dormancy in seeds from mature pods and evaluate the seedling emergence from newly collected seeds in two stages of physiological maturation.

\section{MATERIAL AND METHODS}

\section{Location, collection procedure and processing}

Fruits were collected from eight $E$. crista-galli individuals at two different maturation stages in the location of Banhado da Marambaia (31 $47^{\prime} 30^{\prime \prime} \mathrm{S}$ and $52^{\circ} 18^{\prime} 57^{\prime \prime} \mathrm{W}$ ), Rio Grande municipality, Rio Grande do Sul State. The local vegetation is characterized by the predominance of wetlands, moist fields and swamp forests, which form typical vegetation mosaics for the pioneer formations in the
Pampa Biome (Cordeiro \& Hasenack 2009). The climate of the region is defined as Cfa type, humid temperate climate with hot summers, and no dry season (Alvares et al. 2013).

The evaluation of fruit and seed color according to the Munsell color chart for vegetable tissues was adopted as the criteria for distinguishing maturation stages (Wilde \& Voigt 1977) and fruit dehiscence (Lazarotto et al. 2011, Mello et al. 2013) considering the following: i) immature: green-colored seeds (5GY 7/8) extracted from green pods (5GY 6/10); ii) mature: seeds with brown color (5YR 3/4) extracted from pods beginning dehiscence, dark brown (5YR 3/2). Fruits were collected at different maturation conditions in all mother trees of the same population in order to avoid noise through the addition of intrapopulation variability in the germination analysis. Respecting a minimal distance between mother trees of $50 \mathrm{~m}$ (Sena 2008). The pods were homogenized for both maturation stages, and the seeds were extracted manually. Only intact seeds were selected by visual evaluation, discarding the shriveled or those damaged by insects.

The experiment was conducted in a greenhouse at the Cascata Experimental Station (Embrapa Clima Temperado), Pelotas, Rio Grande do Sul State. Sowing was performed two days after collection, in $55 \mathrm{~cm}^{3}$ containers and commercial substrate (Turfa Fértil ${ }^{\circledR}$ ) with manual irrigation performed twice a day.

\section{Experimental design}

After homogenization and pods processing, the intact seeds and the shriveled/damaged seeds were quantified for the mature collected fruits. The number of seeds per pod was estimated from the average of 100 pods (harvested mature). Next, 600 intact seeds were randomly selected to evaluate seed emergence, which were divided into five treatments: TC - control; T1- sanded (seeds subjected to abrasion with 60-grit sandpaper, on the opposite side of the hilum) and soaked in water for $48 \mathrm{~h}$; T2 - sanded and soaked in water for $24 \mathrm{~h}$; T3 - soaked in water outside of heating at the initial temperature of $60{ }^{\circ} \mathrm{C}$ until reaching ambient temperature; T4 - only sanded; and T5 - immature seeds (Fig. 1). The evaluations were performed every five days for 31 days when the emergence stabilized, and consisted in counting emerged seedlings from visualizing the epicotyl. The experimental design was completely randomized, with four replicates of 25 seeds per treatment.

\section{Emergence measures}

In addition to the emergence percentage ( $\mathrm{E} \%)$, the following measures were calculated in order to evaluate the kinetics of this process: the Emergence Speed Index: $\mathrm{ESI}=\mathrm{E}_{1} / \mathrm{N}_{1}+\mathrm{E}_{2} / \mathrm{N}_{2}+\ldots+\mathrm{E}_{\mathrm{i}} / \mathrm{N}_{\mathrm{j}}$; in which: $\mathrm{E}_{\mathrm{i}}=$ number of germinated seeds and $\mathrm{N}_{\mathrm{j}}=$ number of days after sowing (Maguire 1962), and the Mean Emergence Time: MET $=\sum \mathrm{n}_{\mathrm{i}} * \mathrm{t}_{\mathrm{i}} / \sum \mathrm{n}_{\mathrm{i}}$; in which: $\mathrm{t}_{\mathrm{i}}=$ time between the beginning of the experiment and the $i$-th evaluation; $n_{i}=$ number of seeds which emerged between the evaluation interval of the seeds $t_{i}$ (Borghetti \& Ferreira 2004). 


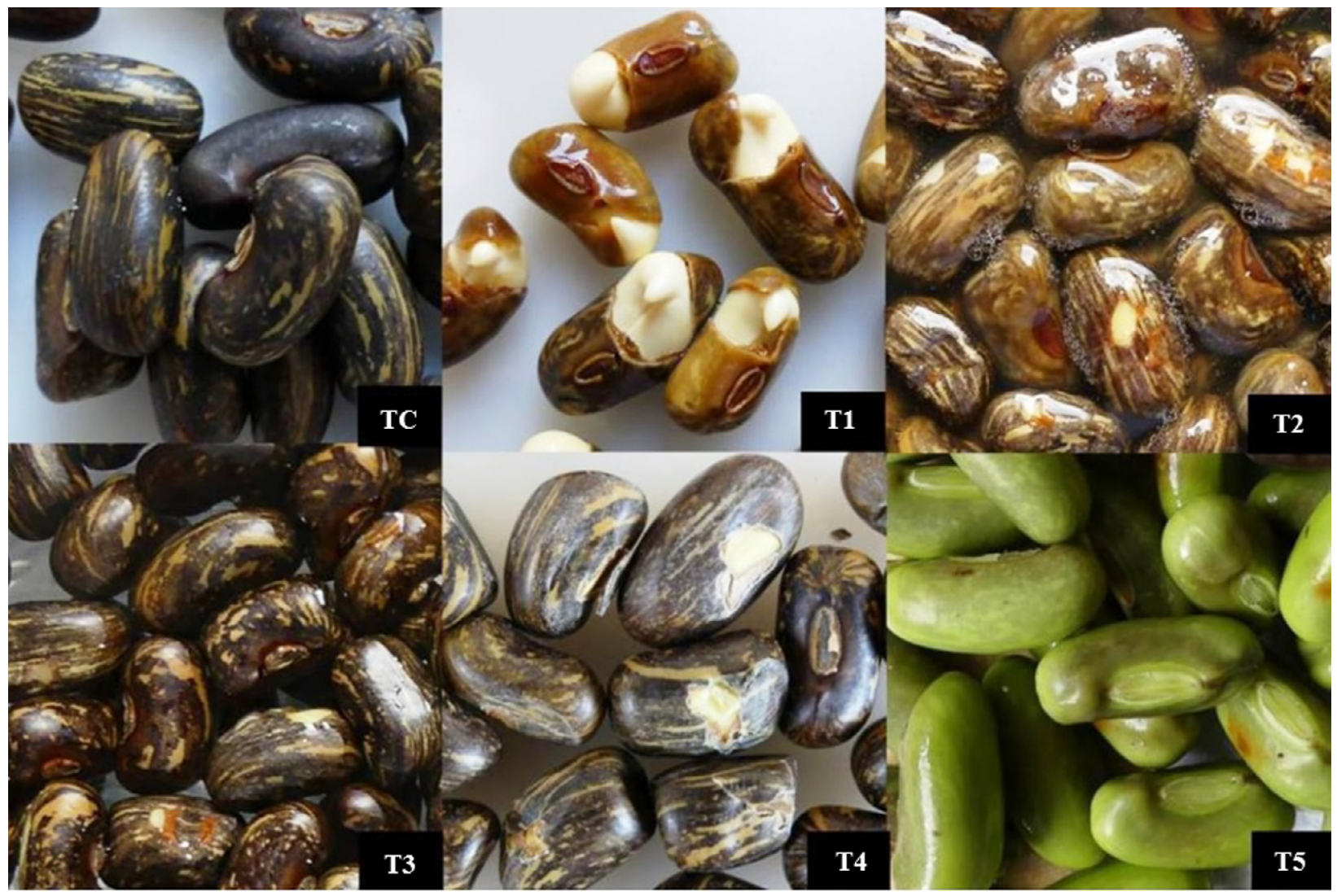

Fig. 1 TC, T1-T5. Erythrina crista-galli. Seeds in different maturation stages and submitted to pre-germination treatments. TC. control; T1. sanded (seeds subjected to abrasion with 60-grit sandpaper, on the opposite side of the hilum) and soaked in water for 48 h; T2. sanded and soaked in water for $24 \mathrm{~h}$; T3. soaked in water outside of heating at the initial temperature of $60{ }^{\circ} \mathrm{C}$ until reaching ambient temperature; $\mathbf{T 4}$. only sanded; T5. immature seeds.

\section{Statistical analysis}

Data were analyzed using the $\mathrm{R}$ statistical software ( $\mathrm{R}$ Core Team 2016), with significance level $(\alpha) \leq 0.05$. The residual normality (Shapiro-Wilk test) (Zar 2013) and the homogeneity of variances (Barlett's test) were previously evaluated (Zar 2013). The E\% and MET variables did not present normality $(\mathrm{W}=0.8465 ; p=0.001[\mathrm{E} \%]$ and $\mathrm{W}=$ $0.898 ; p=0.02[\mathrm{MET}])$ and homogeneous variance $\left(\mathrm{K}^{2}\right.$ $=11.862$; d.f. $=5 ; p=0.04[\mathrm{E} \%]$ and $\mathrm{K}^{2}=20.123$; d.f. $=5 ; p=0.001[\mathrm{MET}])$. The emergence data remained non-normal even after follow-up changes. For this case, we chose to use the non-parametric Kruskal-Wallis test (also called the one-way ANOVA on ranks) (Santana \& Ranal 2004), followed by the Nemenyi post-hoc test for medians (Pohlert 2016).

The MET variable reached normality after the logarithmic transformation $(\mathrm{Ln})$, but did not reach variance homogeneity $\left(\mathrm{K}^{2}=13.833\right.$, d.f. $\left.=5, p=0.0167\right)$, a fact shared by the ESI variable, which presented normality (W $=0.969 ; p=0.654)$, but also did not present homogeneous variance $\left(\mathrm{K}^{2}=15.936\right.$; d.f. $\left.=5 ; p=0.007\right)$. In both cases, we used one factor analyses of variance (ANOVA) with a Tukey post-hoc test for multiple comparisons (Santana \& Ranal 2004), even though it violated one of the four basic assumptions of ANOVA (homoscedasticity), since the data follow the other assumptions (independence, normality and additivity) (Zar 2013). Finally, the medians of the $\mathrm{E} \%$ variable are presented, followed by their respective inter-quartiles intervals $(\mathrm{QRI}=\mathrm{Q} 1-\mathrm{Q}$, where $\mathrm{Q} 1=$ $1^{\text {st }}$ quartile and $\mathrm{Q} 3=3^{\text {rd }}$ quartile), while the mean of the ESI and MET variables are presented followed by their respective standard deviations.

\section{RESULTS AND DISCUSSION}

The pods presented one to 18 seeds (mean \pm standard deviation: $5.77 \pm 3.32, \mathrm{n}=100$ pods). Of the total seeds obtained $(\mathrm{n}=2.188), 38 \%$ were shriveled/damaged by insect, showing a higher number of seeds/fruit and better quality compared with other studies. Lazarotto et al. (2011) obtained an average of 14 seeds/fruit, with four of these seeds/fruit having completed their maturation without damage (28.5\%) and 10 seeds/fruit $(71.4 \%)$ were aborted. Mello et al. (2016) obtained 4.35 seeds/fruit $(n=800)$, in which $53.85 \%$ of the total number of seeds obtained $(\mathrm{n}=$ 3.484) were shriveled or damaged.

Erythrina crista-galli seeds soaked in water with an initial temperature of $60^{\circ} \mathrm{C}(\mathrm{T} 3)$ presented higher seedling emergence rate $($ median $=84$ seeds, $\mathrm{QRI}=4$; Fig. 2$)$, followed by the treatments: control (TC; median $=82$ 
seeds, QRI = 17); immature seeds (T5; median $=80$ seeds, $\mathrm{QRI}=2$ ); seeds only sanded (T4; median $=70, \mathrm{QRI}=8$ ); seeds sanded and soaked in water for $48 \mathrm{~h}$ (T1; median $=$ 30 seeds, QRI $=24)$ and seeds sanded and soaked in water for $24 \mathrm{~h}$ (T2; median $=12$ seeds, $\mathrm{QRI}=8)$.

Seedling emergence among treatments was statistically significant $(\mathrm{H}=18.285$; d.f. $=5 ; p=0.002)$. The Nemenyi multiple comparisons post-hoc test indicated that $\mathrm{T} 2$ differed significantly from T3 $(p=0.010)$, from T5 $(p=0.043)$ and from TC $(p=0.032)$, while there was no significant difference for the other treatments and comparisons ( $p \geq$ $0.05)$. Immature seeds without pre-germination treatments (T5) had similar germination behavior to newly collected mature seeds (T3 and T4), or not (TC), to pre-germination treatments.

The emergence speed index (ESI) varied significantly between treatments (Table 1), with the lowest T2 (3.64 \pm $1.42)$ and the highest T5 $(16.25 \pm 2.15)$. For this variable, the treatments TC, T3, T4 and T5 showed a significant difference in relation to $\mathrm{T} 2$. The mean emergence time (MET) also varied significantly between treatments (Table 1). The lowest was reported for $\mathrm{T} 1(4.73 \pm 1.06)$ and the highest for T3 $(10.96 \pm 0.94)$, with treatments T1 and T2 significantly different from TC and T3.

The effect of different periods and storage methods as well as different treatments for dormancy breaking in E. crista-galli germination were evaluated by Silva et al. (2006). Seeds stored for three months in a refrigerator and without treatment for dormancy breaking obtained $6.7 \%$ of germination, with the best result $(\mathrm{G} \%=59)$ among the treatments being that obtained by immersion in sulfuric acid. When comparing the aforementioned study with the results presented here, it is notable that the treatment with water at $66{ }^{\circ} \mathrm{C}$ outside the heating was considered ineffective by the authors $(\mathrm{G} \%=14)$, whereas a very similar treatment in the present study (water at $60{ }^{\circ} \mathrm{C}$ outside of heating - T3) was the one that presented the best emergence result, but did not differ from the others. Storage possibly triggered the seed coat dormancy process in the aforementioned study.

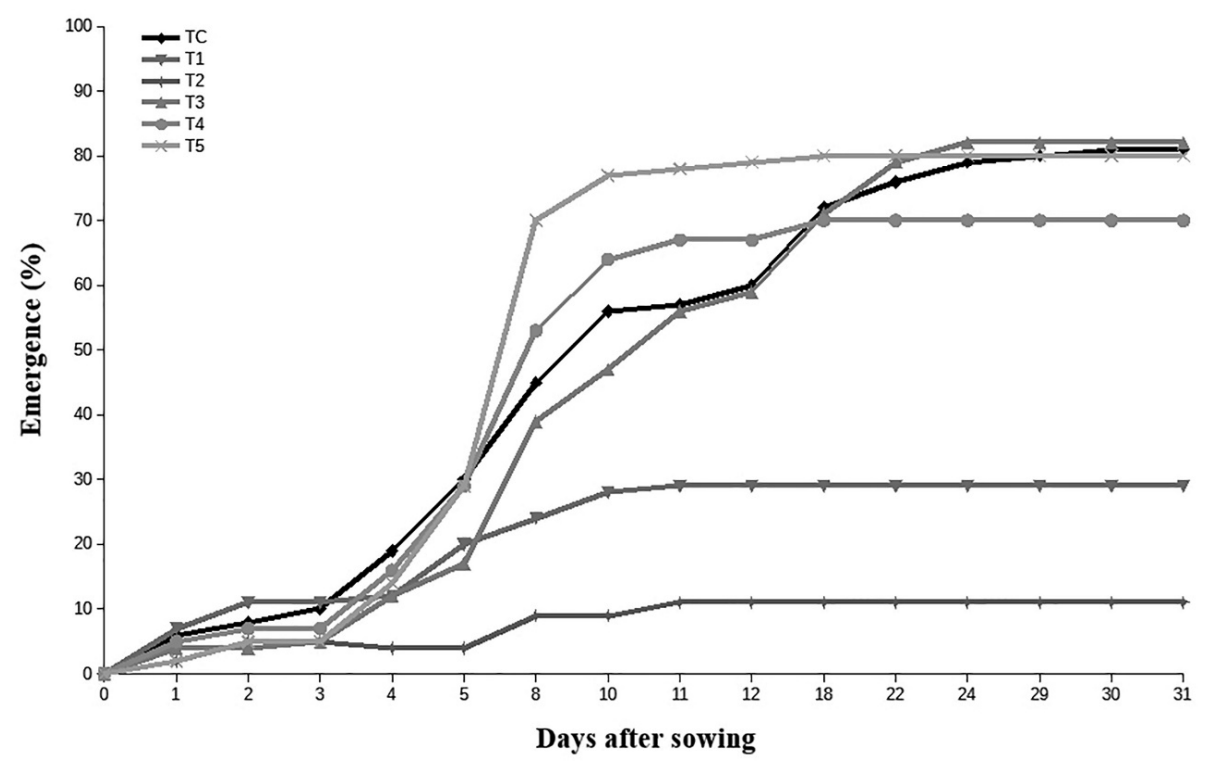

Fig. 2 TC, T1-T5. Seedling emergency (E\%) in relation to the number of days after sowing (DAS). TC. control; T1. sanded and soaked in water for $48 \mathrm{~h}$; T2. sanded and soaked in water for $24 \mathrm{~h}$; T3. soaked in water outside of heating at the initial temperature of $60{ }^{\circ} \mathrm{C}$ until reaching ambient temperature; T4. only sanded; T5. immature seeds.

Table 1. Mean \pm standard deviation for the ESI and MET variables. Equivalent letters mean that treatments do not differ statistically (one factor ANOVA, with Tukey test for multiple comparisons of means, $p \leq 0.05$ ). TC - control; T1- sanded and soaked in water for $48 \mathrm{~h}$; T2 - sanded and soaked in water for $24 \mathrm{~h}$; T3 - soaked in water outside of heating at the initial temperature of $60{ }^{\circ} \mathrm{C}$ until reaching ambient temperature; T4 - only sanded; and T5 - immature seeds.

\begin{tabular}{lcc}
\hline Treatment & ESI & MET \\
\hline TC & $16.08 \pm 8.52 \mathrm{a}$ & $10.69 \pm 4.66 \mathrm{a}$ \\
T1 & $10.45 \pm 1.66 \mathrm{ab}$ & $4.73 \pm 1.06 \mathrm{~b}$ \\
T2 & $3.64 \pm 1.42 \mathrm{~b}$ & $5.92 \pm 1.50 \mathrm{~b}$ \\
T3 & $13.18 \pm 1.32 \mathrm{a}$ & $10.96 \pm 0.94 \mathrm{a}$ \\
T4 & $16.02 \pm 3.96 \mathrm{a}$ & $6.89 \pm 1.21 \mathrm{ab}$ \\
T5 & $16.25 \pm 2.15 \mathrm{a}$ & $6.98 \pm 0.26 \mathrm{ab}$ \\
\hline
\end{tabular}

$\mathrm{ESI}=$ Emergence Speed Index; MET $=$ Mean Emergence Time. 
Silva et al. (2006) also tested methods of overcoming dormancy for seeds stored for 27 months in a cold room and again the chemical scarification presented the best results (95\% germinability), while the "control" (immersion in water at room temperature) reached $12.5 \%$ germinability. Furthermore, these authors obtained 5\% germination (control treatment) to $95 \%$ (chemical scarification) for seeds stored in paper bags for four months without temperature control. Mello et al. (2016) also obtained better results $(\mathrm{G} \%=70)$ with chemical treatment $\left(\mathrm{H}_{2} \mathrm{SO}_{4}\right)$, although the difference in treatment with mechanical scarification was not significant. The seeds that did not receive any treatment presented $10 \%$ germination, and the authors did not mention anything regarding the storage period and form. The data of these studies, when compared with the present research, show results much lower for the control treatments. Apparently, the manifestation of dormancy is related to time and storage conditions.

The data presented here show that newly collected mature seeds have not yet developed tegumentary hardness which is capable of inhibiting germination, since mature seeds not submitted to pre-germination treatments (TC) presented similar germination to other treatments, including immature seeds. This suggests that seed coat dormancy in E. crista-galli is developed after dispersion rather than in the rapid maturation phase. For Lazarotto et al. (2011), the seed coat dormancy in this species begins to manifest starting from ten weeks after anthesis, associated to the low water content found in the seed, thereby resulting in low germination for the material not submitted to pregermination treatments. In general, other Erythrina species present seed coat dormancy, which can be overcome by applying pre-germination treatments (Matheus et al. 2010).

In the present experiment, the material sown $48 \mathrm{~h}$ after collection did not present a significant difference between the control treatment and those which presented the best results, including the immature seeds. The low emergence registered in the treatments with mechanical scarification and subsequent soaking in water at room temperature suggest that these were harmful, although $\mathrm{T} 1$ presented seeds with germination signs (tegument rupture and primary root emission) when still undergoing treatment (Fig. 1).

In some cases, seeds obtained from immature fruits or those collected in initial maturation stages do not present good germination results (Aquino et al. 2006; Godefroid et al. 2010); however, with some exceptions such as Alibertia edulis (Rich.) A. Rich. for which seeds obtained from "green fruits" presented higher germination than those extracted from "mature fruits". Nevertheless, seeds extracted from "green fruits" after 11 months of storage presented $19 \%$ germination, versus $88 \%$ in seeds of "mature fruits" stored for 13 months (Ferronato et al. 1997). Takahashi et al. (2006) affirm that immature seeds can present better germination results, because in addition to not having acquired integument impermeability, they will have been less exposed to attacks from animals and microorganisms. However, the authors recommend that these collected seeds should be sown immediately after collection to avoid damage and germination loss. They also report that anticipation in the collection of seeds to obtain a superior germination rate is only valid for seeds that acquire a certain integument impermeability when they are mature (secondary dormancy), otherwise immaturity will prevent normal germination.

Other factors may influence germination / emergence rates, in addition to those related to conditions and storage time, such as genetic, environmental factors and their possible interactions (Sert et al. 2009). Rego et al. (2005) evaluated the effect of genetic variability on the germination of Albizia lebbeck (L.) Benth. and found an expressive genetic control over the germination of the species. On the other hand, environmental conditions under which the plant is subjected during seed production may interfere with the establishment of physical dormancy (Molizane et al. 2018; Penfield \& MacGregor, 2017). Germination of Erythrina speciosa seeds from the same population followed for six years showed strong interannual variation (Molizane et al. 2018). The authors attribute this oscillation in germination over the years to different degrees of dormancy, correlating it to environmental conditions (i.e. relative humidity) during seed formation.

Erythrina crista-galli seeds newly collected from mature pods in dehiscence do not require treatments to overcome the seed coat dormancy, at least $48 \mathrm{~h}$ after collection. Seeds from immature pods sown as soon as harvested normally germinate. Therefore, pre-germination treatments for this species are unnecessary and possibly harmful. It is recommended future researches with seeds obtained in the same population and at the same time be tested immediately after collection and after different storage periods and conditions, as well as seeds from different populations of E. crista-galli to evaluate genetic and environmental aspects.

\section{REFERENCES}

Alvares, C.A., Stape, J.L., Sentelhas, P.C., Gonçalves, J.L.M. \& Sparovek, P.C. 2013. Koppen's climate classification map for Brazil. Meteorologische Zeitschrift 22(6):711-728.

Aquino, N.F., Bortolini, M., Campagnolo, M.A., Ignácio, V. L., Kopper, A. C. \& Malavasi, M.M. 2006. Dormência de sementes de Peltophorum dubium (Sprengel.) Taubert colhidas em diferentes estádios de desenvolvimento. Scientia Agraria Paranaensis 5(2):31-37. http://erevista.unioeste.br/index.php/scientiaagraria/article/view/2025/1600

Baskin, C.C. \& Baskin, J.M. 1998. Seeds: ecology, biogeography, and, evolution of dormancy and germination. Elsevier, Cambridge. $666 \mathrm{p}$.

Borghetti, F. \& Ferreira, A.G. 2004. Interpretação de resultados de germinação. In Germinação: do básico ao aplicado (A.G. Ferreira \& F. Borghetti, eds.). Artmed, Porto Alegre, p. 209-222.

Cardoso, V.J.M. 2009. Conceito e classificação da dormência em sementes. Oecologia Brasiliensis 13(4):619-631. https://dialnet.unirioja.es/ servlet/articulo?codigo $=3253239$

Cordeiro, J.L.P. \& Hasenack, H. 2009. Cobertura vegetal atual do Rio Grande do Sul. In Campos Sulinos: Conservação e Uso Sustentável da Biodiversidade (V.P. Pillar, S.C. Müller, Z.M.S. Castilhos \& A.V.A. Jacques, eds.). Ministério do Meio Ambiente, Brasília, p. 285-299. http://ecoqua.ecologia.ufrgs.br/arquivos/Livros/CamposSulinos.pdf 
Ferronato, A., Coelho, M. \& Dignart, S. 1997. Germinação e viabilidade de sementes de marmelada-bola (Alibertia edulis LC Rich-Rubiaceae), espécie de uso medicinal em Mato Grosso. Revista Agricultura Tropical 3(1):38-47.

Fowler, J.A.P. \& Bianchetti, A. 2000. Dormência em sementes florestais. Embrapa Florestas, Colombo, 21p. https://www.infoteca.cnptia. embrapa.br/bitstream/doc/290718/1/doc40.pdf

Godefroid, S., Van de Vyver, A. \& Vanderborght, T. 2010 Germination capacity and viability of threatened species collections in seed banks. Biodiversity and Conservation 19(5):1365-1383. https://link.springer. com/article/10.1007/s10531-009-9767-3

Gratieri-Sossella, A., Petry, C. \& Nienow, A.A. 2008. Propagação da corticeira do banhado (Erythrina crista-galli L.) (Fabaceae) pelo processo de estaquia. Revista Árvore 32(1):163-171. http://www. scielo.br/pdf/rarv/v32n1/18.pdf

Lazarotto, M., Beltrame, R., Muniz, M.F.B. \& Blume, E. 2011. Maturação fisiológica de sementes de Erythrina crista-galli L. Ciência Florestal 21(1):9-16. http://www.scielo.br/scielo.php?pid=S1980$50982011000100009 \&$ script $=$ sci_arttext\&tlng=PT

Maguire, J.D. 1962. Speed of germination-aid selection and evaluation for seedling emergence and vigor. Crop Science 2: 176-177.

Martins, M.V. Erythrina in Flora do Brasil 2020 em construção. Jardim Botânico do Rio de Janeiro. Available in: <http://reflora.jbrj.gov.br/ reflora/floradobrasil/FB29674>. Accessed on 11.05.2019.

Matheus, M.T., Guimarães, R.M., Bacelar, M. \& Oliveira, S.A.D.S. 2010. Superação da dormência em sementes de duas espécies de Erythrina. Revista Caatinga 23(3):48-53. https://www.redalyc.org/ pdf/2371/237116334008.pdf

Mello, L.M., Cantos, A.A., Meneghello, G.E., Silva, A.C.S. \& Villela, F.A. 2016. Superação de dormência e influência da temperatura, substrato e fotoperíodo na germinação de sementes de Erythrina crista-galli L.(FABACEAE). Revista Thema 13(3):30-37. http:// periodicos.ifsul.edu.br/index.php/thema/article/view/371/246

Mello, L.M., Cantos, A.A., Silva, A.C.S., Meneghello, G.E. \& Villela, F.A. 2013. Maturação fisiológica, aspectos biométricos e insetos associados a frutos, flores e sementes de Corticeira-do-banhado (Erythrina crista-galli L., FABACEAE), em Bagé, RS. Associação brasileira de tecnologia de sementes 23(3):18-24. https://www.abrates.org.br/ img/informations/0847b4e6-f012-4187-bbd3-027d625b97ab_IA\%20 v23\%20n3.pdf\#page $=18$

Mello, L.M., Lemos, R., Marques, A. \& Stefenon, V.M. 2019. Ancient and Current Distributions of Erythrina crista-galli L.(Fabaceae) in South America. Floresta e Ambiente 26(2):1-9. http://dx.doi. org/10.1590/2179-8087.114417

Molizane, D.M., Julio, P.G.D.S., Carmello-Guerreiro, S.M. \& Barbedo, C. J. 2018. Physical, physiological and anatomical changes in Erythrina speciosa Andrews seeds from different seasons related to the dormancy degree. Journal of Seed Science 40(3): 331-341. http://www.scielo.br/ scielo.php?pid=S2317-15372018000300331\&script=sci_arttext\#B13

Penfield, S. \& MacGregor, D.R. 2017. Effects of environmental variation during seed production on seed dormancy and germination. Journal of experimental botany 68(4):819-825.
Piña-Rodrigues, F.C.M. \& Aguiar, I.B. 1993. Maturação e dispersão de sementes. In Sementes florestais tropicais (I.B. Aguiar, F.C.M. PiñaRodrigues \& M.B. Figliolia, eds.). Abrates, Brasília, p. 215-274.

Pohlert, T. 2016. The Pairwise Multiple Comparison of Mean Ranks Package (PMCMR). R package. Available in: http://CRAN.R-project. org/package=PMCMR. Accessed on 06.14.2017.

R Core Team. 2016. R: A language and environment for statistical computing. R Foundation for Statistical Computing. Available in: http://www.R-project.org. Accessed on 06.14.2017.

Rego, F.L.H., Costa, R.B.D., Contini, A.Z., Moreno, R.G.D.S., Rondelli, K.G.D.S., \& Kumimoto, H. H. 2005. Genetic variability and heritability estimates for the germination trait in Albizia lebbeck parent trees. Ciência Rural 35(5):1209-1212.

RIO GRANDE DO SUL. 1992. Lei nº 9.519, de 21 de janeiro de 1992. Institui o Código Florestal do Estado do Rio Grande do Sul e dá outras providências. Diário Oficial do Estado do Rio Grande do Sul de 21/01/1992. Available in: http://www.legislacao.sefaz.rs.gov.br/ Site/Document.aspx?inpKey=97641\&inpCodDispositive $=\&$ inpDs Keywords $=$. Accessed on 06.15.2017.

Santana, D. G. \& Ranal, M. 2004. Análise da germinação: um enfoque estatístico. Universidade de Brasília, Brasília. 248p.

Sebbenn, A.M. 2002. Número de árvores matrizes e conceitos genéticos na coleta de sementes para reflorestamentos com espécies nativas. Revista do Instituto Florestal 14(2):115-132. https://www.researchgate.net/ profile/Alexandre_Sebbenn/publication/256652269_SEBBENN AM_Numero_de_arvores_matrizes_e_conceitos_geneticos_na coleta_de_sementes_para_reflorestamentos_com_especies_nativas Revista_do_Instituto_Florestal_v_14_n_2_p_p_115-132_2002/ links/559bde5708aee2c16df0271f/SEBBENN-AM-Numero-dearvores-matrizes-e-conceitos-geneticos-na-coleta-de-sementespara-reflorestamentos-com-especies-nativas-Revista-do-Instituto-Florestal-v-14-n-2-p-115-132-2002.pdf

Sena, C.M. 2008. Sementes florestais: colheita, beneficiamento e armazenamento. Ministério do Meio Ambiente, Brasília. 26p. Avaliable in: https://www.mma.gov.br/estruturas/203/_arquivos/ guia_de_sementes_final_203.pdf. Accessed on 11.16.2019.

Sert, M. A.; Bonato, C. M.; Souza, L. A. 2009. Germinação de sementes. In Sementes e plântulas: germinação, estrutura e adaptação (L. A. Souza, org.). Toda Palavra, Ponta Grossa, p. 91-118.

Silva, A.J.C., Carpanezzi, A.A. \& Lavoranti, O.J. 2006. Quebra de Dormência de Sementes de Erythrina crista-galli. Pesquisa Florestal Brasileira (53):65-78. https://pfb.cnpf.embrapa.br/pfb/index.php/ $\mathrm{pfb} / \mathrm{article} / \mathrm{view} / 206 / 156$

Takahashi, L.S.A., Rocha, J.N. \& Souza, J.D. 2006. Revisão sobre produção e tecnologia de sementes de espécies medicinais. Revista Brasileira de Plantas Medicinais 8(4):198-209. http://www.sbpmed. org.br/download/issn_06_3/artigo38_v8_n4.pdf

Wilde, S.A. \& Voigt, G.K. 1977. Munsell color charts for plant tissues. Kollmorgen Instruments, New York.

Willson, M. F. \& Traveset, A. 2000. The ecology of seed dispersal. In Seeds: The ecology of regeneration in plant communities (M. Fenner, ed). CABI Publishing, New York, p. 85-110.

Zar, J. H. 2013. Biostatistical Analysis. Prentice Hall, Nova Jersey. 760p. 